\title{
Effect of dietary inclusion of black soldier fly larvae (Hermetia illucens) on broiler performance : A meta-analysis
}

\author{
Sandi Nayohan ${ }^{1, *}$, Irwan Susanto ${ }^{1}$, Dessy Permata ${ }^{1}$, Raiza Tri Pangesti $^{1}$, Mardiah \\ Rahmadani $^{1}$, and Anuraga Jayanegara ${ }^{1}$ \\ ${ }^{1}$ Nutrition and Feed Technology Department, IPB University, Bogor 16680, Indonesia
}

\begin{abstract}
Black Soldier Fly (BSF, Hermetia illucens) is an insect species that potentially can be used as a protein source for broiler nutrition. This study aimed to evaluate different inclusion level of BSF on broiler performance and blood metabolites by integrating various data from related studies using meta-analysis. Total of 12 studies that comprised of 31 data points were integrated in the database. Parameters observed included Live Weight (LW), Average Daily Gain (ADG), Daily Feed Intake (DFI), Feed Conversion Ratio (FCR), blood metabolites, and carcass proportion. The database was statistically analyzed by using mixed model method. Different studies were considered as random effects, and the level of BSF was treated as fixed effects. The model statistics used were the $p$-values and the Akaike information criterion. The significance of an effect was stated when its $p$-value was $<0.05$. The results revealed that BSF feeding had significant linearly reduction effect on LW, ADG, and FCR of broiler $(P<0.05)$ and significant linearly increase effect on DFI and carcass proportion. However, BSF did not significantly affect on blood metabolites of broilers. It can be concluded that BSF negatively affect the performance of broiler.
\end{abstract}

\section{Introduction}

One of the determining factors for the success of the livestock industry is the availability of quality animal feed. About $50-70 \%$ of production costs are used for feed [1]. Protein source is the most expensive component compared to other nutrient sources. Generally, in some developing countries, protein source come from animal and vegetable proteins such as fish, blood, and soybean. However, the price of these feed ingredients is relatively high. It can burden farmers in terms of production costs. Alternative protein sources that have been researched in recent years are insects. Insects contain high unsaturated fatty acids and can be used as an alternative feed that does not compete with humans.

One of the insects that may be used as an opportunity supply of protein is the Black Soldier Fly (BSF). BSF in poultry rations as protein source is more potential because its availability is relatively abundant in nature and can adapt to a tropical climate. The protein

\footnotetext{
*Corresponding author: nayohansandy5@gmail.com
} 
contained in the BSF may differ depending on the growth medium and the feed given to the magot. According to [2] BSF larvae contain relatively high protein of around 40-50\%, with a fat content of about $29-32 \%$, and the digestibility of BSF pupae is $77.7 \%$.

Efforts to utilize alternative protein source feeds are needed to reduce the importation of protein source. BSF larvae mixed in feed is expected to reduce the cost of feed consumption so that farmers get maximum profit. A meta-analysis study to examine the effect of BSF administration on broiler performance has never been done. Therefore, this study aimed to evaluate the effect of different levels of BSF on the performance of broilers and blood metabolites through a meta-analysis study. This study integrates data from various related journals using a mixed model methodology.

\section{Materials and methods}

\subsection{Research method}

This study was carried out by looking for articles and published data on the utilization of BSF levels on broilers. The literature obtained comes from Scopus and Science Direct 2020-2021. The keywords used in the literature search were "bsf" and "broiler." Based on these keywords, 46 papers were found. Based on the selection results, there were 12 relevant studies used in this study consist of [3-14]. Table 1 provides a statistical overview of the database. The parameters observed in this study include live weight, average daily gain, daily feed intake, feed conversion ratio, blood metabolites, and carcass proportion.

Table 1. Statistical summary of the database regarding effect of dietary inclusion of black soldier fly larvae (Hermetia illucens) on broiler performance

\begin{tabular}{|l|c|c|c|c|c|c|}
\hline Parameter & Unit & $\mathbf{n}$ & Mean & SD & Minimum & Maximum \\
\hline LW & $\mathrm{g}$ & 28 & 2298.1300 & 498.23793 & 1490.00 & 3756.00 \\
\hline ADG & $\mathrm{g} / \mathrm{d}$ & 24 & 69.7100 & 34.00925 & 40.40 & 207.30 \\
\hline DFI & $\mathrm{g}$ & 24 & 114.6538 & 41.83722 & 61.20 & 212.40 \\
\hline FCR & & 24 & 1.7096 & .27420 & 1.47 & 2.34 \\
\hline Metabolite & $\mathrm{mg} / \mathrm{dl}$ & 3 & 79.0300 & 8.66720 & 69.13 & 85.25 \\
\hline Carcass & $\%$ & 14 & 73.6021 & 10.72389 & 57.70 & 93.72 \\
\hline
\end{tabular}

\subsection{Data analysis}

The statistical analysis methodology used in study used a mixed model $[15,16]$. The level of BSF was regarded as a fixed effect in this study, whereas study differences were treated as a random effect. Initially, the quadratic mixed-model method was applied to see the effect of level BSF on the experimental parameters.

\section{Results and discussion}

\subsection{Live weight and average daily gain}

Black Soldier Fly (BSF) is a type of fly (Diptera) from the family Stratiomyidae originating from tropical, subtropical, and warm temperature zones in America. BSF larvae have good 
potential to be used in feeds, especially poultry rations. According to [17], the crude protein level of BSF larvae meal is 44.9 percent, the crude fat content is 29.1 percent, the crude fiber content is 16.4 percent, and the ash content is 8.1 percent. It indicates that BSF larvae are capable of being used as an alternative feed source of insect protein. [18] concluded that BSF meal could substitute fish meal for broiler feed mixtures without affecting dry matter digestibility. According to the findings of the investigation, the administration of BSF meal resulted in substantially different $(P<0.05)$ outcomes in the body weight and body weight increase of chickens (Table 2). These results follow [19] which states that livestock fed $13 \%$ and $20 \%$ BSF larvae meal had a significantly higher difference in body weight than those fed non-BSF larvae meal. The body weight obtained in this study has a bodyweight that tends to be higher than the results of the [20] using the same percentage of larvae meal, which is $15 \%$ of 1785 grams of fish meal. Good body weight and weight gain results can be obtained from an excellent essential amino acid profile.

Table 2. Effect of dietary inclusion of black soldier fly larvae (Hermetia illucens) on broiler performance

\begin{tabular}{|c|c|c|c|c|c|c|c|c|c|}
\hline $\begin{array}{c}\text { Response } \\
\text { Parameter }\end{array}$ & Unit & $\mathbf{n}$ & Intercept & $\begin{array}{c}\text { SE } \\
\text { Intercept }\end{array}$ & Slope & $\begin{array}{c}\text { SE } \\
\text { Slope }\end{array}$ & $\begin{array}{c}\text { P- } \\
\text { Value }\end{array}$ & RMSE & $\mathbf{R}^{\mathbf{2}}$ \\
\hline LW & $\mathrm{g}$ & 28 & 2324.43 & 174.94 & -0.3 & 0.1 & $<0.01$ & 93.28 & 0.98 \\
\hline ADG & $\mathrm{g} / \mathrm{d}$ & 24 & 60.43 & 5.73 & -0.005 & 0.02 & $<0.01$ & 2.34 & 0.83 \\
\hline DFI & $\mathrm{g}$ & 24 & 113.71 & 15.75 & 0.03 & 0.01 & $<0.01$ & 1.69 & 0.99 \\
\hline FCR & & 24 & 1.72 & 0.09 & -0.01 & 0.001 & $<0.01$ & 0.039 & 0.98 \\
\hline Metabolite & $\mathrm{mg} / \mathrm{dl}$ & 3 & 95.15 & 6.88 & -2.68 & 1.06 & 0.24 & 4.51 & 0.86 \\
\hline Carcass & $\%$ & 14 & 71.59 & 4.49 & 0.02 & 0.02 & $<0.01$ & 1.46 & 0.99 \\
\hline
\end{tabular}

\subsection{Daily feed intake and FCR}

In the current study, the different levels of dietary BSF (Hermetia illucens L.) significantly affect on variables daily feed intake $(P<0.01)$ (Table 2$)$. The results of the analysis showed that broiler feed consumption increased following the diet BSF inclusion level. Increased feed intake It is also likely that the chitin content of the BSF worked as a prebiotic in the gut of the broilers, resulting in lower DM digestibility and decreased LW and ADG [21, 22]. Therefore, to meet the metabolic needs, broiler chickens increase their feed intake.

The results were analyzed for variables FCR during the study. FCR showed significantly $(P<0.01)$ affected by the level of dietary black soldier fly (Table 2$)$. The reduction in feed efficiency for every increase in the level of dietary BSF in broiler rations has been obtained, indicating that lauric acid in BSF has a significant antibacterial activity as well as growth promoter potential with minimal toxicity [21]. In this study, feed intake was increase and feed efficiency were enhanced. This shows that there is no effect of dietary The effect of BSF on broiler palatability and the prospect of utilizing BSF in broiler chickens as an alternative to standard lipid sources [7].

\subsection{Blood metabolites and carcass proportion}

This study found that supplementing with BSF meal had no effect on the carcass percentage of broilers (Table 2). The addition of a BSF meal in terms of carcass percentage had no detrimental effect on chicken meat quality. The previous studies have shown no significant 
differences in carcass traits by BSF. A broiler diet with 15\% inclusion of BSF meal showed a negative effect on growth performance and carcass [10]. Other studies on broilers, [9] there was no effect of BSF meal inclusion on carcass weight or carcass percentage in broiler chickens given BSF larvae meal during the growth and finishing stages. [4] for all treatments, the inclusion of BSF meals in the broiler diet had no significant influence on the dressed weight of carcasses (as well as the relative weight of internal organs (liver, heart, spleen, gizzard, and intestines).. In agreement with their result, the present study reported that broiler chicken in the BSF meal group did not affect the carcass cut yield and carcass percentage [3] .

The carcass percentage of broilers trait by BSF meal did not significantly different might be due to the chitin in the exoskeleton of HI larval Chitin was shown to have a detrimental impact on protein digestion. BSF meal has a lot of chitin, which is indigestible and can reduce protein digestibility. Chitin, which cannot be digested, and the microwave drying process of BSF meal might explain these reduced carcass features. This conclusion is consistent with a recent study that found that the carcass weight fell linearly with the inclusion levels $(5,10$, and 15\%) of BSF meal and significantly with a high inclusion level (15 percent). As a result, including a modest level of BSF meal into the broiler diet may help to preserve carcass features. Overall, a modest inclusion level (up to 10\%) of BSF meal looks adequate for broiler diets in terms of chicken meat growth performance, intestinal morphology, and fatty profile of chicken meat [5]. [23] assumed that chitin content in BSF meals was the reason for the crude protein in the BSF meal diet being considerably lower. Chitin in BSF meal influences normal nitrogen-to-protein conversion rates (usually 6.25 for organic matter). [24] determined that a conversion rate of 4.76 is better for predicting crude protein content from measured BSF meal nitrogen levels. Even with a conversion rate of 6.25 , the crude protein content of the BSF meal broiler diet is lower than that of the other experimental diets. Nonetheless, there were no negative impacts on carcass percentage or other meat quality factors.

This study found that include BSF meals in the diet had no effect on blood markers $(P>$ 0.05) (Table 2). These findings are consistent with the findings of [9], who found no significant differences in blood parameters between broiler chickens and turkey poults given BSF feed [7]. The blood parameters reveal information about the birds health. [7] proposed that the broiler chickens were under physiological circumstances and confirmed that BSF meal and BSF fat had no effect on the animals' health state. [7] This action might be attributed to the chelating effect of chitin in the BSF larva feed, according to one study. Chitin, a major ingredient of arthropod exoskeletons, is found in BSF larvae. Chitin concentration in BSF larvae ranges between 5.9 and 8.7 percent.

\section{Conclusion}

The results revealed that BSF feeding had a considerable lowering effect on broiler live weight and average daily growth while increasing daily feed intake and feed conversion ratio. However, BSF did not significantly affect on blood metabolites and carcass proportion of broilers. this show that increasing BSF level on ration negatively affects the performance of broiler.

\section{References}

1. F. A. Katayane, B. Bagau. F. R. Wolayan, J. Zootek, 34, 27-36 (2014)

2. G. Bosch, S. Zhang, D. G. A. B. Oonincx, W. H. Hendriks, J. Nutr. Sci, 3 (2014)

3. T. Popova, E. Petkov, Comptes Rendus L'Academie Bulg. des Sci, 73, 1617-1626 
(2020)

4. M. M. Mutisya, A. K. Mawufe, J. N. Kinyuru, C. M. Tanga, M. Gicheha, G. Hailu, D. Salifu, Z. Khan, S. Niassy, Poult. Sci, 100, 420-430 (2021)

5. B. Kim, H. R. Kim, S. Lee, Y. C. Baek, J. Y. Jeong, H. T. Bang, S. Y. Ji, S. H. Park, Animals, 11, 1-12 (2021)

6. A. F. Ipema, W. J. J. Gerrits, E. A. M. Bokkers, B. Kemp, and J. E. Bolhuis, Appl. Anim. Behav. Sci, 230 (2020)

7. S. Dabbou, A. Lauwearts, I. Ferrocino, I. Biasato, F. Sirri, M. Zampiga, S. Bergagna, G. Pagliasso, M. gariglio, E. Colombino, C. G. Narro, F. Gai, M. T. Capuchio, L. Gasco, L. Cocolin, A. Schiavone, Animals, 11 (2021)

8. M. Gariglio, S. Dabbou, M. Crispo, I. Biasato, F. Gai, L. Gasco, F. Piacente, P. Odetti, S. Bergagna, I. Placha, E. Valle, Elena. Colombino, M. T. Capucchio, A. Schiavone, Animals, 9 (2019)

9. A. Schiavone, S. Dabbou, M. De Marco, M. Cullere, I. Biasato, E. Biasibetti, M. T. Cappucchio, S. Bergagna, D. Dezzutto, M. Meneguz, F. Gai, A. Dalle Zotte, L. Gasco, Animal, 12, 2032-2039 (2018)

10.S. Dabbou, F. Gai, I. Biasato, M. T. Cappucchio, E. Biasibetti, D. Dezzutto, M. Menuguz, I. Placha, L. Gasco, J. Anim. Sci. Biotechnol., 9 (2018)

11. B. Kim, H. T. Bang, K. H. Kim, M. J. Kim, J. Y. Jeong, J. L. Chun, S. Y. Ji, J. Anim. Sci. Technol, 62, 187-197 (2020)

12. B. Kierończyk, J. Sypniewski, M. Rawski, W. Czekała, S. Swiatkiewicz, D. Józefiak, Ann. Anim. Sci, 20, 157-177 (2020)

13. A. Schiavone, M. Cullere, M. De Marco, M. Meneguz, I. Biasato, S. Bergagna, D. Dezzutto, F. gai, S. Dabbou, L. Gasco, A. D. Zotte, Ital. J. Anim. Sci, 16, 93-100 (2017)

14. A. Schiavone, S. Dabbou, M. Petracci, M. Zampiga, F. Sirri, I. Biasato, F. Gai, L. Gasco, Animal, 13, 2397-2405 (2019)

15. D. Sauvant, P. Schmidely, J. J. Daudin, and N. R. St-Pierre, Animal, 2, 1203-1214 (2008)

16. N. R. St-Pierre, J. Dairy Sci, 84, 741-755 (2001)

17. A. Jayanegara, N. Yantina, B. Novandri, E. B. Laconi, Nahrowi, M. Ridla, J. Indones. Trop. Anim. Agric, 42, 247-254 (2017)

18. V. Rambet, J. F. Umboh, Y. L. R. Tulung, Y. H. S. Kowel, Zootec, 35, 13 (2015)

19. J. P. Anankware, R. Ayizanga, O. Opoku, D. Obeng-Ofori. Glob. Adv. Res. J. Agric. Sci, 7, 272-280 (2018)

20. J. Hwangbo, E. C. Hong, A. Jang, H. K. kang, J. S. Oh, B. W. Kim, B. S. park, Journal of Environmental Biology, 30, 609-614 (2009)

21. J. de Souza Vilela, N. M. Andrenicos, M. Kolakshyapati, M. Hiliar, T. Z. Sibanda, N. R. Andrew, R. A. Swick, S. Wilkinson, S. Ruhnke, Anim. Nutr, 7, 695-706 (2021)

22. M. E. Abd El-Hack, M. E. Shafi, W. Y. Alghamdi, S. A. Abdelnour, A. M. Shehata, A. E. noreldin, E. A. Ashour, A. A. Swelum, A. A. Al-Sagan, M. Alkhateeb, A. E. Taha, A. M. E. Abdel-Moneim, V. Tufarelli, M. Ragni, Agric, 10, 1-31 (2020)

23. B. A. Altmann, R. Wigger, M. Ciulu, D. Mörlein, J. Sci. Food Agric, 100, 4292-4302 (2020)

24. R. H. Janssen, J. P. Vincken, L. A. M. Van Den Broek, V. Fogliano, C. M. M. Lakemond, J. Agric. Food Chem, 65, 2275-2278 (2017) 